\title{
A PENOLOGIA PÓS-MODERNA E O DESAPARECIMENTO DO CARÁTER ÉTICO-POLÍTICO DE LEGITIMAÇÃO DO PODER PENAL ESTATAL
}

\section{André Leonardo Copetti Santos}

Pós-doutor pela Universidade do Vale do Rio dos Sinos (Unisinos) e pós-doutorando pela Universidade de Santiago do Chile (USACH). Possui Mestrado (1999) e Doutorado (2004) em Direito pela Universidade do Vale do Rio dos Sinos e Graduação em Direito pela Universidade de Cruz Alta (1988). Atualmente é professor do corpo permanente do Programa de Pós-Graduação em Direito da Unijuí - Ijuí, RS e do Programa de Pós-Graduação em Direito da URI - Santo Ângelo, RS. Coordenador executivo do PPGD/Urisan. Editor da Revista Científica Direitos Culturais. Membro fundador da Casa Warat Buenos Aires e da Editora Casa Warat. Livros e artigos publicados nas áreas de direito penal, direito constitucional, teoria do direito e ensino jurídico. Advogado criminalista. andre.co.petti@hotmail.com

Recebido em: 11/5/2017

Aceito em: 20/6/2017

\section{Resumo}

0 presente artigo tem como objetivo principal desvelar a utilização de um modo de pensar calculador na formulação e justificação das novas políticas penais - Nova Penologia - em que o ser humano é mais um entre vários entes disponíveis para a ação do Estado, em detrimento de uma fundamentação filosófico-antropológica, baseada num pensar meditativo e ético, espaço no qual o ser humano, e seus principais bens - a vida e a liberdade - assumem posição central no processo discursivo de legitimação/limitação do poder penal estatal. Essa nova fase do Direito Penal nominamos como pós-modernidade penal, pois se caracteriza pelo afrouxamento dos sistemas de garantias típicas da modernidade. 0 desenvolvimento da pesquisa utilizou a fenomenologia hermenêutica como matriz teórica e 0 método fenomenológico, consequentemente. 0 resultado do trabalho aponta para um abandono ou esquecimento da fundamentação filosófico-antropológica do Direito Penal, o que tem repercutido na perda do seu caráter garantista. Propositivamente, a investigação conclui pela necessidade de restabelecimento de uma nova ética penal com fundamentação filosófico-antropológica, em que os valores da vida e da liberdade desempenhem papel discursivo e fundamentador central.

\section{Palavras-chave}

Nova Penologia. Pós-modernidade penal. Fundamentação ética. Desaparecimento. 


\section{THE POST-MODERN PENOLOGY AND THE DISAPPEARANCE OF THE ETHICAL-POLITICAL CHARACTER OF LEGITIMATION OF THE STATE CRIMINAL POWER}

\section{Abstract}

The main objective of this article is to unveil the use of a calculating way of thinking in the formulation and justification of the new penal policies - New Penology -, where the human being is one among several entities available for State action, in detriment of a philosophical-anthropological foundation, based on ethical meditative thinking, space in which the human being and his main goods - life and freedom - take center stage in the discursive process of legitimation / limitation of state penal power. This new phase of criminal law we call criminal postmodernity because it is characterized by the loosening of the systems of guarantees typical of modernity The development of the research used the hermeneutic phenomenology as theoretical matrix and the phenomenological method, consequently. The result of the work indicates an abandonment or forgetfulness of the philosophical-anthropological foundation of criminal law, which has repercussion in the loss of its guarantor character. Propositionally, the investigation concludes by the need to reestablish a new penal ethics with philosophical-anthropological foundation, where the values of life and liberty play a central supportive discursive role.

\section{Keywords}

New Penology. Penal postmodernity. Ethical foundation. Disappearance.

\section{Sumário}

1 Delimitando a Hipótese de Trabalho. 2 Sobre as Origens da Tecnocracia Penal Gerencialista. 3 A Nova Penologia no Brasil. 4 Sobre a Prevalência da Fundamentação Tecnocrática-Gerencial do Poder Penal Pós-Moderno em Detrimento da Fundamentação Ético-Política. 4.1. Sobre a (i)legitimidade Ético-Política da Nova Penologia ou Sobre o Esquecimento da Fundamentação Filosófica do Poder Penal Pós-Moderno. 4.2. A Pós-Modernidade Penal entre o Pensar Calculador e a Reflexão Meditativa Ética. 5 Considerações Finais. Uma Decisão para uma Nova Ética Penal. 6 Referências. 


\section{DELIMITANDO A HIPÓTESE DE TRABALHO}

As últimas quatro décadas ou quatro décadas e meia - período que pela sua diferenciação em relaçáo ao projeto moderno de Direito Penal podemos chamar de pós-modernidade penal - marcaram profundamente o universo dos debates e práticas penais, especialmente pelo acontecimento de profundas mudanças que começaram no início dos anos 70, notadamente nos Estados Unidos e na Inglaterra, com caráter marcadamente criminalizatório e encarcerador, e que agora estendem-se por um considerável número de sociedades que se regozijam de seu caráter "absolutamente" democrático, apesar da hiperinflação de seus sistemas penais. Essas tecnologias políticas e jurídicas contemporâneas, que apresentam novas possibilidades aos discursos e às práticas punitivas, são o reflexo de uma mudança fundamental no eixo do poder penal na atualidade, trazido a reboque por um conjunto de modificaçóes e inconstâncias nos mais distintos sistemas sociais que afetam, de forma distinta, diferentes sociedades ao redor do planeta. Essa relação, no entanto, não é uma novidade dos tempos atuais. Praticamente todas as rotinas punitivas preventivas que compóem o arsenal do que Feeley e Simon (1992) classificam como uma "Nova Penologia", e que caracterizamos, em termos políticos, como a pós-modernidade penal, têm paralelos na História, muitas vezes muito mais chocantes do que as atuais medidas propostas pela política criminal atuarial - centro dos debates empreendidos no presente artigo.

A eugenia, o controle da população, o higienismo, a Medicina Social e o controle da loucura por meio das internações em hospitais psiquiátricos desde o surgimento dos asilos no começo do século 19, as esterilizaçôes forçadas no início do século 20, enfim, a execução de medidas punitivas sobre milhares e milhares de indivíduos, simplesmente pelo medo que a maioria "normal" tinha de mantê-los livres e vivos, foram claras expressóes das relações mantidas entre as ciências de ponta dessas épocas, as novas tecnologias por elas produzidas e os sistemas de controle e punição.

Contemporaneamente ressurgem no discurso político-criminal práticas de normalização social de corpos por meio da utilização das novas tecnologias voltadas para a questão do "controle". Nesse contexto, a denominada Política Criminal Atuarial nada mais é do que um conjunto de práticas que visam a solucionar o 
fenômeno da criminalidade apoiadas na lógica econômica - por isso a denominação "atuarial" (proveniente de atuarismo). Isso porque é nos números, nos dados estatísticos, que se busca, na perspectiva atuarial, uma maior eficiência no controle. $\mathrm{E}$ é aqui que se dá a imbricação dessa perspectiva com as novas tecnologias. Nestas, a lógica atuarial encontra o instrumental ideal para uma persecução penal altamente eficiente sem que, para isso, seja necessário um grande dispêndio econômico. Um luxo em tempos de neoliberalismo e de ajustes fiscais.

O fato é que, a partir do momento em que a noção de eficiência no controle da criminalidade e dos criminosos passa a ser a ideia motora da política criminal, evidencia-se um espaço nebuloso no que se refere à proteção das garantias fundamentais dos cidadãos, que passam a ser cada vez mais invasivamente perscrutados, seja por meio de monitoramentos eletrônicos diversos nos espaços públicos, seja pela coleta de dados biométricos, genéticos, etc. O problema, entretanto, é um pouco mais profundo. A questão remota radica-se no campo de justificaçáo do poder penal, ou seja, dos fundamentos, externos ao próprio Direito Penal, do ato de punir, ou, em outras palavras, da legitimaçáo do uso da violência pelo Estado contra os indivíduos como base de um projeto civilizatório.

É nesse contexto que se insere o problema central do presente artigo: o acontecimento da política criminal atuarial, mediante a adoção de uma perspectiva gerencialista como diretriz administrativa das açóes persecutórias penais, ao criar as condiçóes normativo-institucionais para um tensionamento entre o modelo de persecução criminal clássico, assentado sobre as garantias fundamentais do acusado, e um novo modelo totalmente tecnocrático sem maiores preocupaçóes garantistas, não está produzindo o desaparecimento do debate ético-político sobre o crime $\mathrm{e}$ o castigo, ou pelo menos desprezando-o, em favor de uma discussão meramente administrativa de gestáo dos orçamentos públicos dedicados à segurança?

Buscando responder a essa questáo, a investigaçáo direciona-se no sentido de demonstrar que a Nova Penologia possui um déficit de fundamentação filosófico-antropológica, uma vez que prioriza noçóes voltadas tanto à eficiência orçamentária do sistema de administração pública, particularmente o sistema de segurança pública, quanto à valorização do ser humano consumidor, em detrimento de uma compreensão mais humanista do que significa ser humano na sociedade contemporânea. 
Deixar e fazer ver a Nova Penologia por si mesma, tal como se mostra a partir de si mesma, requer uma metodologia que permita tal aproximaçáo ao fenômeno, de modo que permita a ele demonstrar-se diretamente, e não a partir de postulados de outros fenômenos ou de doutrinas tradicionais. A presente proposta de trabalho busca não a abordagem do ente Direito Penal atuarial em particular, mas aspectos do seu ser, aspectos que embora se mostrem de forma implícita e "não tematizada", podem chegar a mostrar-se tematicamente - a sua "legitimação" técnica e não ético-política. Para tal desiderato, o método fenomenológico faz-se não só adequado, mas fundamentalmente necessário, especialmente por que o elemento principal de análise a ser abordado - a fundamentação do próprio Direito Penal contemporâneo - está velado tanto pela sua proximidade e familiaridade em nosso cotidiano, o que faz com que nem notemos e nem nos "pré-ocupemos" com tal aspecto, quanto pelo fato de estar enterrado sob conceitos e doutrinas hauridas a partir de um pensar calculador que impede uma reflexão meditativa a respeito dos limites do poder penal do Estado. Assim, a partir da fenomenologia hermenêutica, buscar-se-á construir o significado da justificaçáo da Nova Penologia desde uma compreensão mais ampla do fenômeno punitivo, cuja interpretação está obscurecida pelos pré-conceitos de interpretaçóes passadas assentadas sobre doutrinas dogmáticas tradicionais.

\section{SOBRE AS ORIGENS DA TECNOCRACIA PENAL GERENCIALISTA}

Do final dos anos 70 do século 20 em diante passou a ocorrer uma grave mudança na orientação das práticas penais, especialmente nos Estados Unidos e na Inglaterra, inaugurando o que pode ser chamado de uma penologia pós-moderna. Tanto a ideologia quanto as práticas penais tornaram-se mais conservadoras, marcando, nesse sentido, um abandono do ideal de reabilitação - cerne da criminologia correcionalista - em direção a políticas criminais de caráter sistêmico, cuja principal característica passou a ser a administraçáo do fenômeno criminal a partir de perspectivas de programação e planejamento orçamentário. Nasce, assim, a política criminal atuarial, mais como planejamento de governo elaborado pelo poder Executivo do que propriamente como resultado de uma reflexáo aprofundada e desenvolvida no âmbito da criminologia, da Sociologia ou da própria Filosofia. 
Por um lado, como destaca Anitua (2008, p. 813), com a renúncia às tentativas de legitimar a pena, e com a resignação na busca de causas que não trariam nenhuma utilidade imediata, grande parte dos funcionários do sistema penal adotou uma "ideologia desideologizada" que os levava a não pretenderem ir além de seus objetivos sistêmicos. Nos anos 70 e 80 do século 20 foram chamadas de "criminologia administrativa" as práticas cotidianas de funcionamento de prisóes, policiais e juízes que se limitavam a cumprir com o que se pretendia deles e evitavam desordens muito evidentes, sem pretender com isso realizar uma mudança sobre a sociedade em geral.

A "reflexão" penológica, mais que tendências investigativas e reflexivas, assumiu um caráter tecnocrático destinado a legitimar a própria ação das burocracias punitivas, sem ter de arriscar o confronto com resultados. Esse acionamento não seria legitimado por algum ideal, mas sim pelo que o sistema penal efetivamente "e’" e "faz". As penas, desse modo, "funcionam", fazem o que fazem dentro desse sistema e é ele que lhes confere razão de existir. Chegar-se-ia a pensar que a maquinaria punitiva "funcionaria" melhor se desconectada desse risco de deslegitimação que se corre ao perseguir uma finalidade inatingível ou infalível da pena. Uma espécie de racionalidade a posteriori passou a alimentar esta estratégia planificadora tecnocrática.

A origem dessa guinada no campo da criminologia e da política criminal pode ser delimitada temporalmente no ano de 1966, quando, então, o recém-eleito prefeito de Nova York, John Lindsay, tomou posse prometendo a reforma do governo da cidade com mais eficiência na relação de custo-benefício orçamentária - o que ficou conhecido naquela época como Sistema de Análise de Orçamentação, Programação e Planejamento (PPBS, em inglês) - e convidou a Rand Corporation para desenvolver novas estratégias para prevenir o crime em Nova York. O PPBS foi pioneiramente posto em prática pelo secretário de Defesa Robert McNamara no Pentágono, tendo começado em 1961, e Lindsay levou a nova técnica para a cidade de Nova York, para melhorar o orçamento e as operaçóes (LIGHT, 2003, p. 67). Em poucos anos, o prefeito Lindsay ajudou a estabelecer o Instituto Rand da cidade de Nova York e a base da corporação na Califórnia. O foco primário do braço nova-iorquino da Rand Corporation seria o Departamento de Polícia de Nova York (NYPD) (LIGHT, 2003, p. 68-72). 
Numa conferência de imprensa, em 8 de janeiro de 1969, realizada com grande estardalhaço, o prefeito Lindsay e o presidente da Rand Corporation e, anteriormente, subsecretário de Defesa adjunto na gestão McNamara, apresentaram o novo projeto: a partir de um contrato inicial de mais de US\$ 600.000,00 com o município de Nova York, a Rand Corporation instalou um escritório na Madison Avenue - um dos redutos mais valorizados e mais explorados economicamente da cidade, que tem sua origem relacionada com a indústria americana da propagan$\mathrm{da}$ - cuidado por 40 economistas, sociólogos, engenheiros, analistas de custos e outros pesquisadores, cujo foco eram quatro áreas, a mais importante das quais era o NYPD (as outras três eram o Departamento de Combate a Incêndios da cidade de Nova York, a Administração de Habitação e o Serviço de Saúde) (REEVES, 1968, p. 68-70).

Em poucos anos o Instituto Rand publicou uma série de análises estatísticas voltadas à prevenção do crime, e tanto esse Instituto quanto a base californiana da Rand Corporation proporiam diversas medidas de justiça preventiva. As primeiras séries de relatórios eram extremamente técnicas, relatórios de pesquisas e operações bastante delimitadas. ${ }^{1}$ Esses estudos aplicaram complexos modelos matemáticos para analisar tempo de despachos de mercadorias e eficiência de roteamentos. Eles se assemelharam às clássicas operaçóes iniciais de pesquisa fora do campo militar para questôes tais como a determinação de "como deveria ser a rota dos caminhóes de coleta do Correio para coletar o material das caixas de depósito de correspondência" ou "que tipo de sistema de aterrisagem para qualquer tipo de clima deveria ser instalado nas novas aeronaves comerciais" (QUADE, 1966, p. 3).

1 Relatórios que, a princípio, nada tinham a ver com matéria criminal, produzidos pelo Rand Institute, serviram de base inicial para a instituição de uma nova penologia através de políticas públicas americanas de administração do crime e dos criminosos instituídas a partir dos anos 70 do século passado. Títulos como "A Hypercube Queueing Model for Facility Location and Redistricting in Urban Emergency Services" (LARSON, 1973), “Urban Emergency Service Systems: an Iterative Procedure for Aproximating Performance Characteristics" (LARSON, 1974), "Response of Emergency Units: The Effects of Barriers, Discrete Streets, and One-Way Streets" (LARSON, 1971), "Allocation of Emergency Units: Response Areas" (CHAIKEN, 1971), "Analysis of the Night and Weekend Arraignment Parts in the Bronx and Queens Criminal Courts" (JENNINGS, 1973), "Using Simulation To Develop and Validate Analytical Emergency Service Deployment Models" (IGNALL; KOLESAR; WALKER, 1975), and "Determining the Travel Characteristics of Emergency Service Vehicles" (HAUSNER, 1975), compóem este arsenal teóricofundante da criminologia atuarial americana. 
Em um sentido muito estrito as operaçóes de pesquisa aplicavam um algoritmo matemático ou modelo para a administração de um problema, tais como, por exemplo, rotas de transporte ou controle de estoque. Para Quade, um dos primeiros e principais pensadores desse novo modo de administrar políticas públicas, a única questão é como aumentar a eficiência do sistema homem-máquina em uma situação na qual não está claro o que significa "mais eficiente". Na ótica do autor, problemas de decisão associados com programas de orçamentação são desse tipo. Nestes, a dificuldade reside na decisão "do que" deve ser feito, além de "como" deve ser feito, não restando claro o que "mais eficiente" significa, e muitos dos fatores no problema frustram a quantificação (QUADE, 1966, p. 4).

Gradualmente, e entremeada com esses relatórios de pesquisa e operações, emergiu uma significativa quantidade de estudos usando a abordagem dos "sistemas de análise” em pesquisas estendidas para além dos estreitos objetivos originais. A abordagem dos sistemas de análises foi um método de abordagem de problemas pela listagem dos objetivos desejados e dos recursos disponíveis (REEVES, 1968). Os estudos dos sistemas de investigação da Rand Corporation na verdade focaram sobre um objetivo bem recortado - a prevenção do crime - e comparariam uma ampla gama de distintas políticas alternativas para tentar determinar a mais eficiente. Dois relatórios formulados por especialista da Rand Corporation são ilustrativos: "Reducing Crimes in Apartment Dwelings: A Methodology for Comparing Security Alternatives", de Michael Liechenstein (1971), e "Criminal Justice Models. An Overview”, de Quade et al. (1975).

Esse último título - "Criminal Justice Models. An Overview” - é um bom exemplo da abordagem preventiva dos sistemas de análise para a questão criminal. Nesse relatório são catalogados 46 modelos de computador destinados a auxiliar a tomada de decisão pelos órgãos de justiça penal. São também descritos cerca de metade desses modelos em detalhes, bem como examinados os fatores que determinam a sua instituição bem ou mal-sucedida, seguidas de conclusôes para a política de investigação federal. Modelos analíticos, simulaçóes, jogos operacionais e modelos de julgamento estruturados em grupo são descritos e organizados de acordo com o assunto abordado: (1) modelos gerais de sistemas de justiça criminal, (2) operaçóes policiais (patrulha e agendamento/programação de pessoal), (3) tribunais e (4) correçôes. A minoria de execuçôes bem-sucedidas foi caracterizada por: compreen- 
são realista das questôes abordadas e período de tempo; documentação orientada para o usuário adequado; e contato pessoal direto do construtor do modelo com o pessoal da agência usuária. Recomendações de políticas incluem: (1) revisão por pares do modelo de financiamento; (2) estudos imparciais de casos de esforços que falharam; (3) exigência de que a pesquisa consolidada seja divulgada por meio da mídia de interesse para o pessoal da agência; (4) disponibilizar um programa de treinamento para eles e (5) um centro federal para programas e documentação que manteria os registros de pedidos de modelos de aplicaçáo (QUADE et al., 1975).

Essa importante transformação na ideologia e nas práticas penais, caracterizada pelo uso de uma "nova tecnologia penal" não garantista, envolve, no entender desses investigadores, mudanças em três distintas áreas:

1. Primeira, a emergência de um novo discurso de fundamentação e legitimação do poder penal: em particular, a linguagem de "probabilidade" e "risco" crescentemente substitui os anteriores discursos de "diagnóstico clínico" e "juízo retributivo".

2. Segunda, a formação de novos objetivos para o sistema: os objetivos que se tem em mente não são simplesmente novos para o sistema (muitos deles têm velhos antecedentes), mas são, em algum sentido, (re)nova(da) mente, "sistêmicos". Há uma primazia dada ao controle eficiente dos sistemas internos que se processa no lugar dos tradicionais objetivos de reabilitação e controle do crime. Metas como a redução da reincidência sempre foram moldadas de diferentes e importantes formas, mas no cenário contemporâneo o sentido de que qualquer referência social externa se destina a todos está se tornando atenuada.

3. Terceiro, o desenvolvimento e a introdução de novas técnicas: essas técnicas tem como alvo o criminoso como um conjunto no lugar de tradicionais técnicas para individualização e criação de equidade.

Essa nova tecnologia penal tem se materializado por intermédio de técnicas de prevenção, tais como: a) práticas de manutenção de ordem baseadas na teoria das janelas quebradas e tolerância zero (controle de comportamentos ameaçadores, embriaguez, vandalismo, realização de pichaçóes, tocar música alta durante a noite); b) elaboração de perfis e investigaçóes preventivas (patrulhas de autoestradas, abor- 
dagens e revistas e açôes antiterroristas); c) incapacitação seletiva e encarceramento em massa; d) expansão de sançôes penais; e) revogação de benefícios na fase de execução (liberdade condicional, por exemplo) a partir de testes de uso de drogas (FEELEY; SIMON, 1992).

Eis, sinteticamente, o germen da atualmente denominada política criminal atuarial, a qual pode ser entendida como uma nova versão repressivista de um Direito Penal não garantidor, nem tampouco ético, cujo modelo estrutural fundante, ao mesmo tempo em que integra Direito Penal, economia e gestão pública, despreza o direito humanitário como fio condutor. Nele, a operacionalidade de base atuarial substitui toda e qualquer tentativa de justificação de um sistema de violência institucionalizada, cujas ficçôes legitimatórias, no plano ético-político, já se encontram em um nível praticamente irreversível de desgaste. Se, porém, a situação dos sistemas penais já é insustentável, mesmo com uma base de reflexão ético-política de legitimação, muito pior ainda quando essa base valorativa de validade discursiva-operacional é absolutamente relegada à insignificância. A escancarada falsidade do discurso penal clássico permitiu a radicalizaçáo de suas piores alternativas pela substituição de sua racionalidade "humanista" por uma versão tecnológica gerencialista-administrativista.

\section{A NOVA PENOLOGIA NO BRASIL}

No Brasil, em um estágio já bem avançado, estamos replicando o modelo punitivo norte-americano, no qual a tônica discursiva é a substituição da sua materialidade essencialmente política por uma substancialidade administrativa, ou seja, o centro da discussão e do interesse acerca da questáo penal ou penitenciária está bem menos radicado no campo ético do que no plano administrativo da gestão pública. No caso americano, temos o exemplo de um Estado de Direito quase irrepreensível, no qual os processos penais oferecem uma multiplicidade de recursos, em que os poderes estão claramente separados e a independência dos juízes não levanta dúvidas, mas, apesar disso, em nenhuma parte do mundo democrático a máquina repressiva conheceu tal sobreaquecimento. $\mathrm{O}$ Brasil não está distante dessa realidade penal e penitenciária americana. O número de encarcerados e controlados pelo sistema prisional brasileiro (mais de 700.000) traduz material e concretamente 
nossa ideologia penal. Agregue-se ao crescimento exponencial de encarcerados as condiçóes imundas e insalubres das penitenciárias nas quais estáo sendo cumpridas as penas, a quantidade de mortes que ocorrem cotidianamente em nossas prisóes e o tratamento que temos dispensado aos nossos menores apreendidos, e veremos que estamos mais próximos do que imaginamos da política repressivista ortodoxa dos norte-americanos, e em alguns critérios até os superamos pela crueldade de nosso sistema prisional.

Dois exemplos contemporâneos ilustram bem a magnitude desse desconchavo. Nos Estados Unidos, considerado o mais amplo sistema democrático do mundo e o lugar por excelência das liberdades, no final do ano de 2014 havia 2.217.947 encarcerados em seu sistema penal, algo aproximado a $25 \%$ da população carcerária mundial, perfazendo uma média de 693 presos por 100.000 habitantes (INSTITUTE..., 2016); no Brasil, uma incipiente democracia num país em desenvolvimento, o número de homicídios chega a uma cifra ao redor de 60.000 ao ano, enquanto a população carcerária, crescendo em volumes alarmantes nos últimos 20 anos, chegou à casa de 607.731 presos, numa média de 299,7 presos por 100.000 habitantes (BRASIL, 2014a, p. 15-16). Ao número absoluto de encarcerados é importante adicionarmos o percentual de crescimento da população carcerária brasileira, a qual chega a uma cifra proporcional de $575 \%$ no período compreendido entre 1990 e 2014. Em 1990 tínhamos ao redor de 90.000 presos, enquanto no ano de 2014 ultrapassamos 600.000 encarcerados. Se ainda somarmos a essa estatística o número de indivíduos que têm sua liberdade restringida mediante prisão domiciliar ou vigiada com aparatos eletrônicos, a situação é ainda mais grave, pois o total da população mantida sob o controle institucional estatal sobe para 711.463 pessoas (BRASIL, 2014a, p. 4), o que perfaz uma relação de 348,75 indivíduos controlados pelo sistema penal para cada grupo de 100.000 habitantes, considerando-se o total da população brasileira tangenciando 204.000 .000 de pessoas.

Em que pese, na atualidade, o número absoluto bem mais alto de encarcerados nos Estados Unidos comparado à população carcerária no Brasil, perfazendo uma proporção de quase 3,7 para 1, a relação entre a tendência de encarceramento nesses dois países é bem diferente nos dias atuais. Nossa inclinação continua seguindo uma curva em franco crescimento, enquanto nos Estados Unidos e outros países como Rússia e China, célebres por seus largos sistemas penais, verifica-se 
uma propensão à estabilização com, até mesmo, uma significativa redução no crescimento do número de encarcerados que começou a se delinear a partir do ano de 2005, havendo, logo após, desde 2008, um decréscimo do número absoluto de encarcerados, com uma inversão no sentido da curva estatística da relação entre o número de prisioneiros por 100.000 habitantes, conforme pode ser observado nas figuras anexadas ao final (ANEXOS 1 e 2 ).

É necessário ressaltar que, tanto no Brasil quanto nos Estados Unidos, estão em vigência sistemas econômicos com algumas regulaçôes estatais que, entretanto, não retiram o seu caráter de livre-mercado, situação que em conjugação com os sistemas constitucionais de liberdades negativas e positivas, bem como com os sistemas político-eleitorais de escolha de representantes baseados em eleiçóes diretas, deixa escancarado o paradoxo, pois inobstante todas essas institucionalizaçóes de proteção e potencialização do desfrute das liberdades civis por um lado - ainda que em termos de direitos sociais os problemas sejam abundantes, especialmente no Brasil - há, por outro, um alto grau de encarceramento e, no caso brasileiro, índices de criminalidade exorbitantes.

Com base nos dados expostos é possível concluir que nos casos americano e brasileiro, e com muito mais intensidade no nosso caso, há a adoção de uma racionalidade administrativa e não mais ético-política sobre o crime, em que somente interessam estatísticas de eficiência sobre o controle de determinados estratos da população. Nos Estados Unidos, a sociedade mais rica do planeta, 2\% da mão de obra potencial em condiçôes de ingresso no mercado de trabalho encontra-se na prisão. E um dos disparates, para ser eufêmico, de nossa época, segundo Larreta (2003, p. 40-41), é que os custos sociais de um semestre numa prisão americana representam o equivalente a um semestre de estudos na Universidade de Harvard.

Também outra conclusão possível e bastante plausível a partir dos dados citados é que, enquanto outros países que experimentaram um grave endurecimento expansionista de seus sistemas penais estão lentamente se distanciando desse modelo, pelo seu desaquecimento, o Brasil, em caminho contrário, está cada vez mais aquecendo seu sistema de repressão penal, com a consequente consolidação do encarceramento em massa de determinadas parcelas da população, especialmente não brancos, pobres e autores de crimes contra o patrimônio. 
$\mathrm{Na}$ conjuntura brasileira, essa tendência político-criminal tem sido a mera consequência de algumas açôes dos poderes públicos, todas dirigidas à ampliação da população encarcerada. O Supremo Tribunal Federal, por exemplo, recentemente, em 17.2.2016, ao decidir pela denegação do HC 126.292, reiterou uma tendência jurisprudencial que há algum tempo já vinha sendo construída nessa Corte, no sentido de possibilitar a execução provisória dos acórdãos penais condenatórios proferidos em grau de apelação, ainda que sujeitos a recurso especial ou extraordinário, entendendo que tal antecipação da pena sem trânsito em julgado não compromete o princípio constitucional da presunção de inocência afirmado pelo artigo $5^{\circ}$, inciso LVII da Constituição Federal. Esse posicionamento jurisprudencial ficou ainda mais consolidado com a decisão prolatada em 10.10.2016, por maioria, pelo Pleno do STF, acerca do pedido de declaração de constitucionalidade do artigo 283 do CPP, formulado nas Açôes Declaratórias de Constitucionalidade (ADCs) 43 e 44, a qual indeferiu a medida cautelar inicialmente concedida, que determinava a suspensão da execução antecipada da pena de todos os casos em que os órgãos fracionários de Segunda Instância, com base no HC 126.292/SP, simplesmente ignoraram o disposto no artigo 283 do Código de Processo Penal.

O STF, com essa decisão, agrega-se a outras esferas de poder, as quais, nos últimos 25 anos, aproximadamente, estão voltadas, por meio de suas açóes institucionais, à ampliação da atuaçáo repressiva do Estado, tal como aconteceu, por exemplo, com a Câmara dos Deputados, ao aprovar, em meados de 2015, a PEC n. 171-D, que tratou da redução da maioridade penal de 18 para 16 anos, ou com o Senado, que não tendo apreciado esta PEC da Câmara, já aprovou o PLS n. 333/2015, que altera o Decreto-Lei no 2.848/1940 (Código Penal), a Lei no 8.069/1990 (Estatuto da Criança e do Adolescente - ECA) e a Lei no 12.594/2012 (Sistema Nacional de Atendimento Socioeducativo), para estabelecer que é circunstância agravante a prática do crime com a participaçáo de menor de 18 anos de idade, que o ECA se aplica excepcionalmente a pessoas entre 18 e 26 anos de idade e que poderá ser adotada a medida socioeducativa de internação em Regime Especial de Atendimento, após os 18 anos de idade, pelo período máximo de 10 anos.

Ainda no campo legislativo, vale lembrar, a título exemplificativo, a Lei $n$. 8.072/90 (Crimes Hediondos), a Lei n. 10.792/03 (modificou a Lei de Execuçóes Penais criando o Regime Disciplinar Diferenciado), a Lei n. 12.850/2013 (Crime 
Organizado), os Decretos n. 7.267/11 (Monitoração Eletrônica) e n. 7.950/13 (Perfis Genéticos), sem falar nas inúmeras leis penais incriminadoras surgidas após a promulgação da $\mathrm{CF} / 88$, as quais determinaram uma significativa expansão do Direito Penal (COPETTI SANTOS, 2010, 2011).

Esse novo Direito Penal atuarial contém algumas fórmulas e instituições que se constituem num perigo real e efetivo a todo e qualquer sistema de garantias positivado constitucionalmente, especialmente em países com frágeis democracias constantemente fustigadas pelas mazelas dos desequilíbrios econômicos e sociais. Nesse aspecto, duas delas, entre outras já aqui mencionadas, representam um risco mais agudo às liberdades: a consagração do critério de periculosidade do agente ou de parcelas da população com determinadas características e o arbítrio judicial.

A acentuação do enunciado da fórmula de periculosidade como critério para o tratamento penal e preventivo - critério fundamental, praticamente básico e único no caso dos imigrantes e do terrorismo - póe em destaque a impossível tarefa de fazer catálogos completos de situaçóes perigosas, dado que a periculosidade é um conceito altamente subjetivo, e cada ser humano, em particular, pode representar um caso distinto e particular. As garantias dos direitos, sobretudo individuais, representadas pela definição do delito - nullum crime sine lege - e pela pena fixada de antemão em relação ao fato - nulla poena sine praevia lege - parecem receber um duríssimo golpe, mais decisivo ainda quando se trata de submeter a tratamento ou encarceramento pessoas ou grupos que ainda não delinquiram, ou cuja culpabilidade não foi apurada definitivamente.

Por outro lado, o arbítrio judicial - fenecido nas mãos da Revolução Francesa - ressuscita contemporaneamente com novas instituiçóes legais, por exemplo, a delação premiada, quando promotores resolvem quase despoticamente a quem a oferecem e juízes decidem, com alto grau de discricionariedade, pela sua homologação ou não. $\mathrm{O}$ que é preciso não deixar passar incólume é o fato de que tais expedientes inquisitoriais e processuais têm sido usados para beneficiar indivíduos que enriqueceram com seus crimes, especialmente contra o Estado, e cujas consequências penais revelam, mais uma vez, a seletividade do sistema penal, pois praticamente todos os beneficiados têm reduçóes drásticas de penas, as quais são cumpridas em regime domiciliar, podendo os beneficiários desfrutarem de todos os 
benefícios obtidos com seus crimes. Em sentido contrário, a quase totalidade dos presos do sistema carcerário brasileiro, além de não gozarem de qualquer benefício dessa natureza, ainda enfrentam as terríveis condições de nossas casas prisionais.

Instituiçôes penais e processuais penais com tal funcionalidade não se concebem sem o arbítrio ministerial e judicial. Adaptaçóes da pena ou o reconhecimento do estado de periculosidade precisam absolutamente do arbítrio dos juízes e de outras corporaçóes do sistema de administração da Justiça. Com isso, os fantasmas retornam. Ao postular hoje a amplitude do movimento dos julgadores, ressurgem os riscos da injustiça e dos atropelos de antanho.

\section{SOBRE A PREVALÊNCIA DA FUNDAMENTAÇÃO TECNOCRÁTICA-GERENCIAL DO PODER PENAL PÓS-MODERNO EM DETRIMENTO DA FUNDAMENTAÇÃO ÉTICO-POLÍTICA}

O conjunto dessas novas fórmulas e instituiçôes revela, no mínimo, dois grandes processos de distanciamento: primeiro, a separação dessas novas políticas criminais de qualquer discurso de fundamentação/legitimação filosófica do Direito Penal; segundo, o afastamento dessa nova tendência do poder penal em relação à base ética de projetos políticos estruturados por meio de modelos constitucionais democráticos de Direito.

Essas situações não podem ser desconectadas da pesada influência que vem exercendo sobre as políticas criminais, já há algum tempo, um forte movimento populista penal, no qual o senso comum revela uma natureza fortemente anti-intelectual em relação às questôes penais. Os investigadores das questóes criminais, em razão do populismo penal, não são mais relacionados como práticos ou comentadores privilegiados, sobre cuja experiência ou especialização repousam as respostas a respeito desse campo de problemas, mas, em sentido totalmente distinto, são vistos, negativamente, como obstáculos no caminho das mais legítimas demandas do público em geral. Essa situação favorece, definitivamente, que a vontade do povo seja preferencialmente injetada no processo de formulação de uma decisão pública, em detrimento das pesquisas de especialistas a respeito dos temas da criminalidade, 
da punição e da segurança pública. A consequência disso é que as bases eleitorais joguem um papel muito mais importante na determinação das políticas criminais do que propriamente criminólogos, sociólogos, filósofos ou juristas especializados.

Esse fenômeno contemporâneo tem servido muito para mudar os termos do debate sobre a questão criminal, deslocando os consensos políticos de bases científicas e filosóficas sólidas sobre a criminogênese e os limites e legitimidade da intervenção estatal penal, para o lugar das ideias e expectativas do povo em geral, e nesse sentido, de acordo com Pratt (2007, p. 12), "o populismo penal fala de um modo no qual criminosos e prisioneiros são pensados para serem favorecidos a expensas das vítimas do crime em particular e do público cumpridor da lei em geral”, o que alimenta expressóes de ódio, desencantamento e desilusão em relação ao sistema de justiça criminal e aos investigadores especialistas e filósofos que refletem sobre o tema. Nesses termos, o sucesso de nosso sistema de justiça criminal é mensurado pela quantidade de pessoas presas e pelo número de presídios construídos - quanto mais presos mais exitoso é o sistema - do que pela sua eficácia em evitar a pena privativa de liberdade e, em uma relação inversamente proporcional, prevenir a criminalidade sem a utilização de políticas criminais de natureza estritamente penal. Anedotas, ditados populares e experiências pessoais parecem estar mais aptas a comunicar a autenticidade de experiências criminais e apresentar soluçôes do que estatísticas, estudos científicos e reflexôes filosóficas sobre a conveniência da utilização em massa do poder penal estatal.

É nesse quadro contextual que temos de emoldurar o real significado do fenômeno de rotulação de leis penais com nomes de vítimas particularizadas (por exemplo, Lei n. 11.340/2006, Lei Maria da Penha, que regula situaçóes ligadas à violência doméstica; Lei n. 12.737/2012, Lei Carolina Dieckmann, que prevê o crime de invasão telemática; lei n. 13.010/2014, Lei Menino Bernardo, que normatiza o direito da criança e do adolescente de serem educados e cuidados sem o uso de castigos físicos ou de tratamento cruel ou degradante). Seguimos, nesse aspecto, mais uma vez, uma tendência esboçada inicialmente nos Estados Unidos e, em seguida, importada por nós sem maiores questionamentos, como já ocorreu fartamente com nosso constitucionalismo e também com o nosso sistema penal. Essa questão vai muito além da simples nomeação da lei: significa o rompimento com o anonimato frio dos procedimentos da justiça criminal, dando ares de hu- 
manização à legislação e captura a força emotiva que a vitimização carrega consigo. Às vozes das vítimas ou à voz daqueles que clamam (geralmente sem autoridade, em absoluto, para fazer) para falar sobre seus interesses foi dada uma autenticidade e uma validade em relação ao desenvolvimento de políticas de controle do crime, enquanto a autoridade e a influência dos especialistas em justiça criminal foi rebaixada e reduzida (PRATT, 2007, p. 18). Em outras palavras, o amplo diálogo inclusivo do qual devem participar, na medida do possível, todos os potencialmente afetados pelo fenômeno criminal de uma maneira ampla, tem sido constantemente fraturado, para dele excluir algumas partes importantes nesse processo de construção dos sistemas punitivos.

Os sistemas penais, apesar de todas suas imperfeições, são respostas no campo prático/institucional que devem nos remeter, mais remotamente, a um diálogo moral que temos e queremos fortalecer e restabelecer em casos de ruptura, como são as situaçôes criminais. Em que pese esse imperativo, entretanto, com a Nova Penologia parece estar ocorrendo um hiato na relação entre o Direito Penal e Filosofia, para dar lugar a uma estreita relaçáo entre o Direito Penal, a economia e a gestão pública a partir de uma visão sistêmica. Esse, provavelmente, seja um problema fundante da Nova Penologia, pois incide diretamente sobre a construção do imaginário penal e suas consequentes possibilidades de ação num determinado tempo e espaço.

\subsection{Sobre a (I)Legitimidade Ético-Política da Nova Penologia ou Sobre o Esquecimento da Fundamentação Filosófica do Poder Penal Pós-Moderno}

O fato, grandioso e terrível, que põe, na modernidade, nas mãos do Estado o direito de punir, deve sempre ser objeto de profundas investigaçóes, especialmente no campo filosófico, quando se trata de questionar a sua pretendida legitimidade. Não é suficiente afirmar, como inúmeros doutrinadores o fazem, que se trata de um direito subjetivo do Estado, ou que faz parte do processo de funcionalização do ente estatal o monopólio da violência legítima. É preciso mais do isso; é necessário investigar profundamente seus fundamentos. Apesar do famoso apotegma 
homines non requirunt rationes carum rerum quas semper vidente, ${ }^{2}$ não basta que o poder penal estatal tenha existido quase imemorialmente para que seja tido como justo, e tampouco é aceitável - como acreditaram alguns dos partidários do tecnicismo jurídico encabeçados por Manzini (1941, p. 7) - separar esses problemas da preocupação do penalista, afirmando que a investigação filosófica é repudiada por ser supérflua e danosa, ou afirmar, como Magri, que a penalidade não se justifica "por teorias filosóficas", mas por "um critério de necessidade (1923, p. 113 et seq.).

Nossas instituições repressivas não surgem abruptamente da cabeça de legisladores, mas são, diferentemente, resultado de um lento processo social sob o impulso de concepçôes filosóficas dominantes, solicitaçôes políticas preeminentes realizadas pelas forças hegemônicas, necessidades ou imposiçôes econômicas, tendências científicas, das tradiçôes e da consciência jurídica de um povo e do progresso (BETTIOL, 1966, p. 7-8). Como bem observam Zaffaroni et al., os autores liberais do século 19 consideraram que a Filosofia era fonte de conhecimento do Direito Penal; em geral suas obras começavam expondo seu ponto de partida filosófico. Era natural que assim procedessem aqueles que procuravam derivar da razão seus sistemas de Direito Penal, o que, por outro lado, se impunha ante a pobreza ou carência do fundamento constitucional: o poder punitivo devia ser contido a partir de uma ideologia da qual se derivavam os princípios limitadores. Na luta contra o poder do Estado, como bons herdeiros da Ilustração, eles esgrimiam a razão em primeiro lugar (2003, p. 187). Com essa postura investigativa, um exemplo marcante é a Escola Clássica que encontrou em Carmignani, Rossi e Carrara seus expoentes sistemáticos mais ilustres e que teve como precursores Beccaria e Romagnosi, escritores que, por aspectos particulares, foram mais políticos e filósofos que juristas, por terem sido estudiosos que se ocuparam principalmente em reagir contra o sistema penal arcaico, ainda em vigor no final do século 17, e em explicar a origem racional do direito de punir. Característico dessa Escola é, antes de mais nada, o método de trabalho. O que hoje parece ser uma verdade apodítica, ou seja, que o jurista deva tomar como ponto de partida de toda construção, o Direito Positivo vigente foi, para os cultores da Escola Clássica, uma premissa metodológica quase desconhecida, pois trabalhavam baseados em critérios de razão, e não simplesmente sobre dados

2 Os homens não requerem razóes caras para as coisas que sempre veem. 
de uma experiência jurídica (BETTIOL, 1966, p. 13). É desnecessário destacar o avanço humanista e humanitário que tal Escola representou para o Direito Penal moderno, especialmente em termos de limitaçóes ao poder penal do Estado.

Quando, em uma segunda etapa do acontecimento do Direito Penal moderno, os princípios liberais foram recebidos e incorporados aos estatutos políticos (Constituiçóes), os sistemas se construíram sobre a base de leis positivas e o prestígio da Filosofia, como fonte de Direito Penal, debilitou-se (ZAFFARONI et al., 2003, p. 187). Em etapas posteriores chegou-se ao limite de rechaçar qualquer influência da Filosofia sobre o Direito Penal e de considerá-la prejudicial, como sucedeu com Manzini, conforme antes mencionado. Em geral, desde que se impôs a construção do sistema de Direito Penal em conformidade com as regras dogmáticas não se atribui mais à Filosofia o caráter de fonte.

Essa situação de total distanciamento entre Filosofia e Direito Penal se agudizou, contemporaneamente, com o surgimento da Nova Penologia, pois subjacente a ela repousa a pergunta acerca do fato de ser a eficiência sistêmica no controle/prevençáo da criminalidade a única medida a ser sopesada. A partir disso, algumas perguntas são inevitáveis: Existem limites éticos que devem ser considerados fundamentais em um Estado Democrático de Direito? Como coadunar tais práticas - invariavelmente invasivas - de prevenção com a ideia de privacidade e liberdade constitucionalmente asseguradas? Essas indagaçóes surgem na medida em que, de acordo com Hudson (2012, p. 43), percebe-se que todos os projetos de prevenção lastreados na lógica atuarial revelam um uso indiscriminado, uma vez que eles "têm por alvo qualquer pessoa de uma certa área da cidade; qualquer pessoa com uma certa identidade racial ou religiosa; qualquer pessoa que seja um estranho", razão pela qual "a ideia de que somente os culpados tenham algo a temer não é tão verdadeira como muitos de nós gostaríamos de acreditar”.

A razão administrativa eficientista tornou-se hegemônica em detrimento de qualquer razão ética humanista, priorizando-se, nesse sentido, as vantagens para o sistema administrativo, num sentido geral, na sua relação com os indivíduos e grupos populacionais. As razóes éticas, próprias aos projetos políticos constitucionalizados sob a forma democrática de Direito, em que as relaçóes entre os seres humanos, visando aos maiores índices possíveis de vida boa, ocupam posiçôes privilegiadas, têm sido gradualmente substituídas por razôes economicistas orçamentárias, nas 
quais os principais bens a serem protegidos são a eficiência do sistema - no caso particular, do seu braço violento, o Direito Penal - e a integridade e continuidade das relaçóes de produção.

Convém aqui considerar que mais do nunca é preciso restituir à Filosofia sua condição de fonte do Direito Penal, e nesse sentido, a antropologia filosófica juntamente com a ética desempenham papéis de fundamental importância no processo de reumanização do saber e do poder penal do Estado, situação absolutamente distinta da que se projeta a partir da Nova Penologia.

Qual a concepção de ser humano, ou melhor, de "não-ser humano" que tem funcionado como pano de fundo das proposiçóes penais da Nova Penologia? Em A Crise de Legitimação do Capitalismo Tardio (2002), um estudo inicialmente publicado no ano de 1973, em pleno crepúsculo da sociedade dos produtores, quando apareciam já os primeiros sintomas do amanhecer iminente da sociedade dos consumidores, Jürgen Habermas realizou uma famosa e memorável caracterização do Estado capitalista. O objetivo central deste, segundo o autor alemão, é a reprodução contínua dos componentes básicos da sociedade capitalista, dos quais esta se reabastece contínua e constantemente e com os quais vai se revigorando no transcurso de sua própria autorreprodução. Esses componentes básicos essenciais são os encontros (regulares) entre capitalistas e trabalhadores que culminam na transação das compras e vendas. A função primeira do Estado capitalista, assegurava Habermas (e, no fundo, a função que faz dele um Estado "capitalista", ou o que é o mesmo, um Estado a serviço da reprodução da sociedade sob uma forma capitalista), é procurar as condiçóes necessárias para que tais encontros sigam tendo lugar. E as duas condiçôes estreitamente interconectadas que devem cumprir-se para que tais encontros se produzam com regularidade e consigam seu propósito são que o capital seja capaz de pagar o preço da mão de obra, e que a mão de obra que se oferece esteja em condiçóes apropriadas para que aos capitalistas (seus compradores potenciais) resulte atrativa sua aquisição.

A esses dois componentes básicos essenciais propostos por Habermas, Bauman acrescenta um terceiro. Para o sociólogo polonês, na atualidade, já imersos plenamente na sociedade de consumo, é como se a função do Estado capitalista houvesse passado a ser a de provedor de um novo e completamente distinto "componente básico essencial” do edifício capitalista que substituiu recentemente a esse 
seu modelo predecessor que Habermas descreveu em seu livro: o encontro entre o cliente e o artigo ou mercadoria de consumo. Hoje, afirma Bauman, as condiçóes para que essa transaçáo de compra e venda tenha lugar de forma regular e com a frequência suficiente passam por assegurar que o cliente esteja em situaçáo de pagar o preço da mercadoria ofertada e de que esta seja suficientemente atrativa para ser vendida a esse preço (2016).

Esse terceiro "componente básico essencial" apresentado por Bauman, como caracterizador da última versão da sociedade capitalista - a sociedade de consumo -, constitui-se em elemento essencial a uma concepção de não ser humano que alimenta valorativamente a Nova Penologia. É uma pesada negação de qualquer compreensão antropológico-filosófica do que pode ser o ser humano e de qualquer compreensão de um agir ético humanista que possa alimentar relaçóes sociais voltadas ao bem-estar, especialmente quando falamos nas possibilidades de relaçóes que possam emergir socialmente a partir do funcionamento de sistemas de controle e punição. Uma olhada mais cuidadosa para os alvos do confinamento/exclusão resultante da execução da Nova Penologia nos revelará que os "indesejados", os representantes das "baixas colaterais" da globalização econômica, do consumo e do lucro sem precedentes, os representantes da "subclasse" que, mesmo estando “dentro", estão "fora”, são aqueles cujos corpos e cujo tempo não estão à disposição dos processos reprodutivos dessa nova versão do capitalismo e, portanto, precisam ser separados, incapacitados, controlados. A história se repete, e mais uma vez é preciso dar razão a Rusche e Kirchheimer quando afirmam:

Todo sistema de produção tende a descobrir puniçóes que correspondem às suas relaçōes de produção. É, pois, necessário pesquisar a origem e a força dos sistemas penais, o uso e a rejeição de certas puniçóes, e a intensidade das práticas penais, uma vez que elas são determinadas por forças sociais, sobretudo pelas forças econômicas e conseqüentemente fiscais (1999).

Diante da agudeza das crises econômicas dos últimos tempos, a Nova Penologia inventou novas fórmulas de punição para, exatamente, aqueles que não só não contribuem para a reprodução do sistema econômico, mas o afrontam, pondo em risco a estabilidade de suas relaçôes. São os pobres, mais uma vez, os imigrantes, os que não tendo trabalho organizam suas próprias atividades econômicas dentro 
de um campo social de atividades definido como ilícito, como os traficantes, em razão da existência de um mercado ávido por seus produtos, enfim as novas versóes dos inimigos do capitalismo, como já foram os vagabundos, os vadios, os pródigos ou os chineses consumidores de ópio que ocupavam os espaços de trabalho dos norte-americanos no século 19.

O Direito Penal da modernidade, e não é diferente com a versão pós-moderna materializada na Nova Penologia, ao se aproximar de uma razáo econômica, especialmente capitalista, seja em sua versão produtivista, seja consumerista, sempre precisou dar as costas para as reflexóes antropológicas e filosóficas acerca da compreensão epocal do que é o ser humano e como devem ser a relaçóes entre eles para uma vida boa, e para isso sempre lançou mão de uma concepçáo de homem, de ser humano adequado ao sistema e de seres não adequados, portanto, não seres humanos, não homens. Essa é a carga não humanista que sustenta a Nova Penologia, negando qualquer possível fundamento oriundo da Antropologia e da Filosofia.

\subsection{A Pós-Modernidade Penal entre o Pensar Calculador e a Reflexão Meditativa Ética}

A Nova Penologia é, em grande parte, decorrência dessa nova concepção de homem - o homem consumidor - pois sendo ele o ser que importa para o sistema capitalista, os não consumidores, os ameaçadores do "íntegro" funcionamento do sistema capitalista precisam, como corolário das políticas criminais de ocasião, ser anulados, incapacitados, segregados. Essa concepção de homem e todas as suas repercussóes em termos de controle social penal excessivo e violento dos indesejados é uma clara consequência de um pensar e agir técnico, calculador, no qual impera uma crescente carência de pensamento sobre o ser humano que está consumindo o próprio ser humano. Há uma fuga em pensar o humano no modo-de-ser calculador. Com as palavras do próprio Heidegger, esse tipo de pensar próprio caracteriza-se pelo fato de que

sua peculiaridade consiste em que à medida que planificamos, investigamos, organizamos uma empresa, contamos já sempre com circunstâncias dadas. Nós as tomamos em conta com a intenção calculada de algumas finalidades deter- 
minadas. Contamos, pois, antecipadamente com determinados resultados. Este cálculo caracteriza todo pensar planificador e investigador. Semelhante pensar permanece sendo cálculo ainda quando náo opera com números nem ponha em movimento máquinas de somar nem calculadoras eletrônicas. O pensamento que conta, calcula; calcula possibilidades continuamente novas, com perspectivas cada vez mais ricas e, ao mesmo tempo, cada vez mais econômicas. $\mathrm{O}$ pensamento calculador corre de um estado ao seguinte, sem deter-se nunca nem parar para meditar. $\mathrm{O}$ pensar calculador não é um pensar meditativo; não é um pensar que pense desde o sentido que impera em tudo quanto é (1994, p. 4).

Com a Nova Penologia, na qual a justificação tecnocrática substituiu a motivação ética filosófica, criou-se um quadro que não tem a potência legitimatória suficiente para dar ao Direito Penal um sentido democrático e humanista, pois o que deveria ser um campo - o Direito Penal - de reflexão e ação voltado a melhorar as relaçóes entre os seres humanos - na medida em que isso é possível diante do braço repressor violento do Estado - um caminho que conduziria a uma vida humana mais feliz, sempre com uma fundamentação ético-política, tornou-se um âmbito de açóes detido pelas tenazes da planificação, da cibernetização e do empenho automatizado em segregar, excluir e violentar.

Pode parecer paradoxal, mas não há como evitar afirmar que a Nova Penologia representa o velho e o novo em termos de um modo de ver o mundo. $\mathrm{O}$ velho, porque é o desdobramento, uma reediçáo dentro de um campo regional como o Direito Penal, de uma posiçáo do homem no mundo e com respeito ao mundo, na qual o mundo e o homem aparecem como objetos aos quais o pensamento calculador dirige seus ataques, e aos quais nada parece poder resistir. Se Heidegger já alertava acerca de que a natureza se converte em uma única estação gigantesca de combustível, em fonte de energia para a técnica e para a indústria modernas, similarmente podemos fazer o mesmo alerta em relação ao homem atual diante da Nova Penologia, pois o ser humano indesejado se transforma em náo ser humano e, como consequência, objeto de controle técnico de outros seres humanos.

Por outro lado, a Nova Penologia, ao lançar máo das mais recentes tecnologias cibernéticas e eletrônicas para o controle representa o novo em termos de configuração do Estado e da democracia, ou da não democracia. Se, por um lado, como aponta Levy (2003), os meios de comunicação interativos, as comunidades 
virtuais sem território e a explosão da liberdade de expressão permitida pela Internet abrem um novo espaço de mais comunicaçáo, transparente e universal de resto, levado a profundamente renovar as condiçóes da vida pública no sentido de uma liberdade e de uma responsabilidade acrescidas do cidadão, por outro, não há como esquecermos as reflexôes de Deleuze (2010) acerca da sociedade de controle, quando cada vez mais assistimos à utilização das invençôes de última geração para o controle dos indivíduos.

O desenvolvimento do ciberespaço já suscitou práticas políticas novas, que podem ser avaliadas tanto positiva quanto negativamente. Se, por um lado, observamos o surgimento de comunidades virtuais de base territorial, que são as cidades e regiôes digitais, criando possibilidades de uma democracia local de rede mais participativa, por outro assistimos à passagem para uma governação eletrônica, cujas consequências serão não só o reforço das capacidades de açáo das populaçóes administradas, mas também um aumento exponencial das possibilidades de as subjugar a um poder controlador (câmeras eletrônicas, tornozeleiras, perfis genéticos, etc.).

Uma nova forma de Estado parece estar inevitavelmente emergindo de forma progressiva, seguindo a novas leis de governança, em que a informatização garante não só a potencialização dos níveis de articulação (global, continental, nacional, regional ou metropolitano), mas também impulsiona o surgimento de zonas de interseccionamento entre a lei e os sistemas institucionais de justiça com a economia, a técnica e a ciência, os quais cada vez mais são em suas particularidades fundamentais dentro de uma unidade fundamental, o que garante, cada vez mais, eficácia no controle, não sendo diferente no âmbito penal. Nesse sentido, a Nova Penologia confirma, no plano penal, as proféticas palavras de Heidegger acerca do modo-de-ser técnico:

Em todas as regióes da existência o homem estará cada vez mais estreitamente cercado pelas forças dos aparatos técnicos e dos autômatos. Os poderes que, em todas as partes e em todos os momentos, desafiam, acorrentam, arrastam e acossam o homem sob alguma forma de utilização constante de utensílios técnicos ou no âmbito da instalação técnica, estes poderes há muito tempo que já não se encontram sob o alcance da vontade e da capacidade de decisóes humanas, isto porque não foram feitos pelo homem (1994, p. 10). 
A técnica, em companhia da ciência, da alocação da arte no campo da estética, da transformação do fazer humano em cultura e da "desdivinização" da existência, é um fenômeno em que se expressa um modo-de-ser da nossa ocidentalidade, sua tendência fundamental (HEIDEGGER, 1979). Essa tendência técnica começou já na Antiguidade, com Platão e Aristóteles. Esclarecer essa indicação e estabelecer a conexão com o que está subjacente ao novo discurso penológico nos obriga a voltar às questôes primárias e primordiais da Filosofia: as interpretaçôes de ente e ser.

Tudo o que tem manifestação, concreta e tangível, ou abstrata, incorpórea, virtual, é ente. Não há discordâncias sobre isto no pensamento filosófico, mas, no que se refere ao ser, as posiçôes divergem e, na verdade, é exatamente essa discussão que acaba por constituir a Filosofia.

Segundo Heidegger, desde Platão e Aristóteles teve início uma época no Ocidente cuja tendência foi a de demarcar e firmar um acordo tácito sobre uma interpretação a respeito do ser: que o ser é a noção, o juízo, o conceito do ente. ${ }^{3}$ Desde então, ser é tomado e tratado como uma ideia dos entes, de sua identidade, portanto, sua definição. Definição, porém, que é construída por meio de um método (indução e dedução) e comprovada logicamente (as provas da identidade, da não contradição e do terceiro excluído).

Tal delimitação do ser como juízo e a postulação de certa metodologia para sua produção é reafirmada e ampliada na Idade Moderna, inicialmente com Descartes. Com ele, o juízo ou a definição do ente (o ser) ganha uma restrição. O que importa ao pensar é a mensuração e o cálculo do ente, única maneira de se garantir e assegurar sua manifestação. O pensamento, por meio do Cógito ou Razão, certifica-se do ente. $\mathrm{O}$ método inicialmente apresentado por Aristóteles para se obter o conceito dos entes e que se voltava para a obtenção de sua essência ou substância é alterado desde a modernidade em favor da observação, classificação, generalização, previsão e controle dos entes - obras do cálculo da razão. O que puder ser apreendido por esse processo metodológico é entâo reconhecido como real.

3 Veja Aristóteles, Livro X da Metafísica (1970). 
O resultado desse novo processo é o que Heidegger identifica como a representação do ente. Representação é a recriação do real na medida do cálculo da razão. O real é a reconstrução calculadora do real: representaçáo do real. Em outras palavras, o real é a ideia do real.

A representação calculadora, portanto, não olha para o real a partir dele mesmo, mas das possibilidades representativas da razão. Olha para a lente com que se deve olhar para o real e, então, requisita o real a partir dela. Ao ajustá-lo à medida da lente, a representação calculadora realiza uma certa provocação (pró-vocação) do real. Ela o convoca a mostrar-se sempre da mesma maneira. Lança o real diante de si como objeto dessa provocaçáo representativa. Assim, opera em relaçáo ao real um controle sobre sua possibilidade de manifestação. A esse poder de interpelação produtora está subordinado tudo o que é e pode ser: o existir diário dos homens, as ciências, a indústria e a economia.

O que Heidegger compreende como sendo a essência da técnica moderna, como estamos vendo, confunde-se com a essência mesma de nossa ocidentalidade (CRITELLI, 2002, p. 86).

A humanidade do homem, que na modernidade se estabeleceu sobre a razão calculadora, se amplia e sobrepuja na figura da técnica. É o agir técnico que dá ao homem, hoje, sua essência. Para esse modo de ser viemos nos entregando desde há muito, à medida que o reconhecemos como a única e mais verdadeira possibilidade de cuidar de nosso ser-no-mundo. Procuramos o domínio sobre o ente. Viemos constituindo a técnica como nosso modo de existir e lançando-a a nossa frente, consequentemente, como nosso destino. Há, portanto, um trajeto histórico que viemos percorrendo, em que nos enredamos como num círculo vicioso. Somos impelidos pela técnica que lançamos diante de nós como nossa requisição e única possibilidade. A técnica é, assim, essencialmente, uma modificação sui generis do fazer ou do agir humano. Nas palavras do próprio Heidegger:

Se pensarmos a técnica a partir da palavra grega téchne e de seu contexto, técnica significa: ter conhecimentos na produção. Téchne designa uma modalidade de saber. Produzir quer dizer: conduzir à sua manifestação, tornar acessível e disponível algo que, antes disso, ainda náo estava aí como presente. Este produzir, vale dizer o elemento próprio da técnica, realiza-se de maneira singular, 
em meio ao Ocidente europeu, através do desenvolvimento das modernas ciências matemáticas da natureza. Seu traço básico é o elemento técnico, que pela primeira vez apareceu, em sua forma nova e própria, através da Física moderna. Pela técnica moderna é descerrada a energia oculta na natureza, o que se descerra é transformado, o que se transforma é reforçado, o que se reforça é armazenado, o que se armazena é distribuído. As maneiras pelas quais a energia da natureza é assegurada são controladas. O controle, por sua vez, também deve ser assegurado (1972).

Todo esse processo exige um asseguramento, isto é, a certificação de que poderá ser sustentado e repetido sempre que necessário. $\mathrm{O}$ que garante o asseguramento do processo é o pensamento que calcula as possibilidades de sua realização, e que é do domínio do que Heidegger chama ciências matemáticas da natureza, por meio da Física moderna. Tal processo produtivo não se circunscreve à interferência nos processos da natureza, mas se alastra a todo agir humano e de tal sorte que essa interferência requisita e propóe todos os nossos saberes, produçóes e comportamentos. $\mathrm{O}$ modo de agir (ou ser, no caso) do homem ocidental tornou-se técnico. Trata-se de uma orientação de conduta que aplicamos a cada gesto e em relação a tudo. É esse o único modo que entendemos ser possível no trato de nossa existência e do que quer que nela se apresente.

Como olhamos para o mundo e para o existir desde essa ótica técnica, tudo o que faz parte do mundo fica subordinado a ela. Os elementos naturais, por exemplo, ficam compreendidos e disponibilizados para esse tipo de agir. Assim, uma floresta perde a sua condição primordial de floresta e se restringe a ser reserva de madeira para a indústria; as plantas ficam disponibilizadas como reserva para a produção de remédios; os rios tornam-se reservas para o uso das hidroelétricas e a produção de energia, e assim por diante (HEIDEGGER, 2002).

Esse modo tem tudo a ver com a representação moderna de verdade e, assim, com a ciência experimental. $\mathrm{Na}$ imagem moderna do mundo a natureza aparece como um complexo de forças passível de ser calculado. Cálculo e experiência são maneiras de fazer com que a natureza "se anuncie" como uma totalidade concebida. A técnica não deve, pois, ser vista como uma aplicação eventual da ciência; à natureza como complexo de forças passível de ser calculado corresponde a disponibilidade do ente para dominação e utilização. Afirmar, pois, que a técnica 
já está posta no próprio núcleo essencial da ciência moderna é um passo a mais na direção da compreensão da essência técnica, porque essa conjunçáo corresponde a um apelo da época, que o homem deve atender e mediante o qual visa a justificar a sua posição histórica. $\mathrm{O}$ modo peculiar de desabrigamento que está envolvido na técnica moderna corresponde ao destino que o homem deve cumprir (LEOPOLDO E SILVA, 2007, p. 371-372).

O que significa essa disponibilidade do ente como forma de presença perante a qual também o homem se faz disponível para requerer da natureza a satisfação de suas necessidades pela via da transformação técnica? A palavra alemá usada por Heidegger pode ser traduzida como "armação". Uma estante tem uma armação que não se confunde com suas prateleiras ou com seus parafusos. Toda estrutura possui uma "armação" pela qual ela permanece, precisamente enquanto essa armação está para além de todos os elementos da estrutura. A armação, portanto, reúne os elementos e, de alguma forma, sustenta-os sem se confundir com qualquer deles atravessando-os todos, se assim se pode dizer. A cordilheira reúne "originariamente" a sequência de montanhas e as "atravessa”. Esses exemplos visam a aproximar-nos de uma ideia extremamente difícil de ser definida: o próprio Heidegger assinala que a palavra está sendo usada em um sentido "completamente incomum".

Dois aspectos importantes merecem destaque. "Armação" refere-se ao modo próprio de desocultar que corresponde à essência da técnica moderna. E "Armação" refere-se a algo que nada tem de técnico. Isso quer dizer que se examinássemos a técnica em todos os seus elementos e eventualmente viéssemos a conhecer todos eles, ainda assim a essência da técnica permaneceria oculta, pois conhecer a técnica como trabalho, instrumento ou meio equivale a visar às determinaçôes antropológicas que nela estão contidas, mas que não revelam sua essência. Desviando-se dessa representação humanista, Heidegger pretende atingir o modo como na "armação" acontece o "des-cobrimento" pelo qual o homem é provocado a desabrigar o ente de um modo peculiar que corresponde, como já visto, à consideração da natureza como um reservatório de energias que ele pode utilizar. A "armação" seria, assim (ainda aproximadamente), a própria disponibilidade, ou a reunião "originária" dos elementos disponíveis, pela qual os entes se apresentam para o homem por meio da representação calculante da ciência. Disso deriva, aliás, a impressão de que a técnica moderna será ciência aplicada. 
A relação entre desocultamento e disponibilidade indica, assim, o modo específico pelo qual o homem experimenta a técnica e experimenta-se nela. Que isso seja o cumprimento de um destino é algo que não anula a liberdade humana, que deve ser compreendida tanto como o destino que se oferece ao homem quanto como o modo pelo qual o homem se oferece a esse destino. Nessa dupla relação reside o perigo da técnica. Digamos, a propósito, que Heidegger não faz coro com aqueles que veem na técnica a perda do humano ou sua inevitável alienação. Não se trata propriamente de julgar a técnica, mas sim de compreendê-la em sua essência como modo de desvelamento, entretanto, e isso é importantíssimo destacar, a disponibilidade do ente como "forma" geral da técnica pode incidir na relação entre o homem e a técnica, fazendo-o incluir-se inteiramente entre os entes disponíveis, perdendo assim a sua diferença. É notável que Heidegger sublinhe que isso pode acontecer justamente quando o homem se investe na condição de senhor e dominador da Terra pela via da técnica. Quanto mais esse senhorio for valorizado, mais o homem será uma simples peça do esquema da disponibilidade. O homem não mantém autonomia em relação à disponibilidade técnica, fazendo-se "sujeito" da técnica. Pelo contrário, essa atitude indicaria antes a submissão e impotência. A técnica é um destino que se oferece ao homem, e ele deve cumpri-lo, mas se não compreender esse destino e se ignorar esse apelo, submergirá no domínio da técnica. Para isso, é preciso ouvir o apelo e compreender o destino, por paradoxal que possa parecer, esse consentimento à liberdade.

A crescente carência de pensamento sobre o ser humano, que está consumindo o próprio ser humano, a fuga em pensar o humano no pensar calculador, mostra, assim, sua estreita relação com essa inclusão do ser humano entre os entes disponíveis, perdendo, dessa forma, a sua diferença enquanto ente que possui o privilégio ôntico de ser ontológico, isto é, ao contrário dos outros entes, enquanto ente que compreende o ser dos entes.

Após esse breve parêntese sobre a questão do modo-de-ser técnico na teoria heideggeriana, retornemos a nossa questão central - a falta de fundamentação ético-política do novo discurso penológico - relacionando uma coisa com a outra. No item 2 retro, quando tratamos da origem da Nova Penologia, nos Estados Unidos, estão explícitos alguns elementos que trazem à luz o modo-de-ser técnico que lhe subjaz. Vejamos: 
- utilização de análises estatística voltadas à prevenção do crime, com base nas quais foram propostas diversas medidas preventivas;

- utilização de relatórios de pesquisas e operaçóes bastante delimitadas, que, a princípio, nada tinham a ver com a questão criminal, mas que, estendidas para além dos estreitos objetivos originais, serviam de base para a instituição de políticas públicas de combate à criminalidade;

-aplicação, nas operaçóes de pesquisa, de algoritmos matemáticos ou modelos para administração de um problema;

- emprego de modelos de computador para auxiliar a tomada de decisão pelos órgãos da Justiça criminal;

- adaptaçóes de modelos analíticos, simulaçóes, jogos operacionais e modelos de julgamento estruturados em grupo e organizados de acordo com o assunto.

Esses elementos são a máxima e clara expressão de uma razão calculadora empregada nas novas tecnologias penais, cujo efeito concreto mais sentido é o encarceramento em massa, que concebe determinados grupos de seres humanos, aqueles indesejados ao sistema econômico ou aos sistemas políticos nacionalistas, como totalmente disponíveis para o agir penal. Nesse sentido, não é o homem que está na prisão, mas a prisão que está no homem, como elemento central estruturante de um cálculo de planificação e organização social sem qualquer lastro de fundamentação ético-política.

Há, nesse modo de pensar calculador penal, um grau de violência imensurável. Não só a violência física que é a parte mais visível dos sistemas penais, com as mortes e condiçóes sub-humanas em penitenciárias, com as mortes de policiais e dos indivíduos perseguidos pelas agências estatais, mas também dois outros tipos objetivos de violência: a simbólica, pertencente ao campo da linguagem e que se manifesta na imposição de um certo universo de sentido, e a sistêmica, que consiste nas consequências muitas vezes catastróficas do funcionamento regular de nossos sistemas econômico e político (ŽIŽEK, 2014, p. 17).

Essa violência objetiva, da qual as novas tecnologias penais são uma das mais violentas, senáo a mais furiosa manifestação institucionalizada estatalmente, assumiu uma nova forma com o capitalismo. A criminalização da miséria, da mo- 
bilidade humana pelas migraçóes, a incidência massiva dos sistemas penais sobre determinados estratos étnicos da população, são a consequência mais palpável da ação de sistemas que ultrapassam a vontade individual. Esse monstro autopoiético chamado capitalismo, expressão paroxística do pensar calculador, segue seu caminho ignorando qualquer preocupação com o humano. $\mathrm{O}$ ser humano é mais um entre os demais entes disponíveis para o cálculo.

Por isso, faz-se necessário, urgentemente, reestabelecer uma continuidade fundamental entre a Filosofia moral, a Filosofia política e o Direito Penal, como forma de restabelecer uma reflexão meditativa de cunho ético acerca das possibilidades do que podemos fazer uns com os outros quando há, nas relaçóes sociais, comportamentos desvalorados a ponto de serem rotulados como crimes. Antes de mais nada, é preciso repensar que partes estão envolvidas no fenômeno penal. Antes de haver uma relação entre sistema e indivíduos, há uma relação entre seres humanos, os quais devem ser compreendidos em toda sua diferença em relação aos demais entes - não estamos disponíveis para o cálculo como estão as pedras - e em todas suas diferenças individuais e comunitárias entre si, sociais e culturais, para fins de análise de quais comportamentos podem ser realizados ou não, universal e particularmente, tendo em vista a possibilidade de aplicação de puniçôes. Como bem explicita Hannah Arendt (1993), não é o Homem, mas são os homens que habitam a Terra, ou como adverte Levinas (1986, p. 23-24):, "Minha relação ética de amor pelo outro está enraizada no fato de que o eu (self) não pode sobreviver sozinho, não pode encontrar sentido apenas em sua própria existência no mundo" Nesse sentido, é evidente que para além do campo, além do conhecimento do mundo e da história na qual nossa existência acontece, precisamos nos interessar pelos outros humanos, por aqueles com os quais vamos interagir. Por que não apenas não estamos sós, mas, além disso, o simples processo de educação mostra que não poderíamos simplesmente nascer e subsistir sem a ajuda de outros humanos, a começar por nossos pais. Como viver com o outro, que regras adotar, como nos comportar de modo "vivível”, útil, digno, de maneira "justa” em nossas relaçôes com os outros? Essa é a questão que permite o desvelamento do campo da ética na Filosofia, uma parte não mais tanto teórica, mas prioritariamente prática (FERRY, 2007, p. 33), e cuja relação com o Direito é estreitíssima. 
Parafraseando Robert Nozick, quando este diz que "a filosofia moral arma o palco e estabelece as fronteiras da filosofia política”, afirmamos que a Filosofia moral estabelece o pano de fundo e as fronteiras da Filosofia política e esta os limites e possibilidades do Direito Penal. $\mathrm{O}$ que as pessoas podem e não podem fazer umas às outras (Filosofia moral) limita o que podem fazer por meio do aparato do Estado ou para estabelecer este aparato (Filosofia política), imperativos que se aplicam diretamente ao Direito Penal, pois há, necessariamente, limites para o que podemos considerar relevante seja no estabelecimento do aparato normativo, tanto no marco da positivação de tipos penais quanto dos castigos correspondentes, seja na execução concreta das punições. E nesse sentido, razão total assiste mais uma vez a Nozick ao afirmar que "as proibições morais permissíveis que ela pode fazer cumprir constituem a fonte de qualquer legitimidade que tenha o poder coercitivo fundamental do Estado" (1991, p. 20). Em outras palavras, os acordos e desacordos normativos estabelecidos nos campos da Filosofia moral abrangente e da Filosofia política projetam-se, inevitavelmente, para o campo de normatização jurídica, e com muito mais força para o campo de normatização penal, especialmente em razão da necessidade de uma justificação mais profunda para um ramo de atuação estatal marcado por graves níveis de violência institucionalmente legitimada, cujo potencial para injuriar territórios do agir ético não são nada desprezíveis.

\section{CONSIDERAÇÕES FINAIS. UMA DECISÃO PARA UMA NOVA ÉTICA PENAL}

Segundo Heidegger, o que viemos esquecendo nessa caminhada histórica foi o ser. A técnica nada mais é do que a reificação do ente e a retificação ininterrupta do primado do seu domínio. A humanidade, assim, ao hegemonizar um modo-de-ser técnico, calculador, agregando Levinas a Heidegger, é uma ruptura do ser. Quando aceitamos, numa decisão historial, que o ser corresponderia ao conceito sobre o ente, igualamos ser e ente. Esquecemo-nos de que o ser é tudo: o que falamos, o que projetamos, o que cuidamos, mas sua consistência é a de um vapor, como ressaltava Nietzsche. O ser é tanto as possibilidades de serventia que descobrimos nos entes (um pedaço de madeira "é" um pé de mesa, um calço, uma arma...), como nosso próprio destino, cuja determinação é sempre impossível. O ser se faz, mostra-se, revela-se, torna-se disponível nos entes, mas se recolhe. 
Num exemplo do próprio Heidegger (1969), quando tomamos nas mãos um pedaço de giz, o que seguramos é uma massa branca, quebradiça, etc. Seu ser (ser giz) se dá quando o usamos e não quando falamos dele e queremos defini-lo. $\mathrm{E}$ o mais interessante, exatamente quando o giz "é" propriamente giz, em uso, é nesse momento que ele vai deixando de ser. Nesse consumir-se do giz é que o giz é giz. Aí ele vai resvalando para o Nada, mas insistindo em seu ser. E quando esse pedaço de giz acabar, onde estará o ser giz? E quando esse giz não estiver à minha frente disponível como essa coisa com que escrevo, mas eu usá-lo como massa para fechar um buraco na parede? Ou quando usá-lo como um dardo que atiro em alguém para chamar sua atenção? O ente giz continua aí, mas seu ser, suas possibilidades de ser se transmutam, somem, alternam-se. Por esse caminho de uma indagação ontológica é que temos que pensar o ser humano. Não por sua utilidade ou não para um sistema econômico ou político, ou por sua disponibilidade para um pensar calculador, mas em suas múltiplas possibilidades existenciais, criativas e afetivas, numa projeção erótica e não tanática, como possibilidade de liberdade.

O que Heidegger quer nos dizer é que o ser é sempre as possibilidades que descobrimos nos entes e que nos empenhamos por realizar. Possibilidades às quais damos realidade quando as empreendemos. Heidegger quer nos dizer que o ser é o possível do mundo e de nós mesmos, mas um possível entregue aos nossos cuidados e sob nossa responsabilidade. Que possibilidade de mundo estamos criando quando optamos por um agir que, desprezando o Outro e suas precariedades, privilegia a supressão da liberdade em níveis multitudinários, em atendimento a razōes injustificáveis moralmente?

Tal quadro está a nos exigir uma religação da Filosofia, da política e do Direito Penal como forma de construção de uma nova ética penal, substitutiva do pensar e agir calculador imanente à Nova Penologia. É nessa perspectiva que Critelli (2002) nos "pro-voca”, nos instiga, a partir de Heidegger, à vocação de uma nova ética, em que o caminho inaudito para o Ocidente está no abandono decisivo do domínio sobre o ente e a entrega ao ser em seu poder-ser. Está no salto para fora do círculo vicioso da interpelação produtora, do pensar e agir calculador, ainda mais quando nos referimos ao plano das relaçóes sociais, das possibilidades do pensar e agir de seres humanos sobre outros. De onde viria, todavia, essa possibilidade de abandono e entrega? Essa possibilidade de transcendência? Certamente, não de dentro desse 
círculo fechado do Ocidente e que se constituiu em sua essência. Certamente, não do apelo do mesmo. Seria preciso que pudéssemos ouvir um outro chamado que não esse que brota do hábito do controle, da representação controladora, da interpelação produtora. Ouvir esse outro chamado implicaria que pudéssemos estar livres desse hábito, desgarrados dele. Ouvir outro chamado e descobrir outra possibilidade para nosso destino histórico, outra possibilidade para cuidarmos do ser exige uma passagem pelo silêncio. Requer uma parada no vazio, no qual se possam esmorecer as determinaçóes, os vícios da técnica, as explicaçôes da ciência... Ouvir um outro chamado significa tampar os ouvidos para o mesmo, para o que já se sabe. Ficar em silêncio. E o silêncio é passagem. Tempo de esvaziamento e disponibilidade para a nova palavra, para a nova luz, para o novo apelo. O novo caminho para o Ocidente é a abertura para o que lhe é inaudito e desconhecido. Especificar esse inaudito é impossível, exatamente por ele ser inaudito.

A modernidade, entretanto, tem se caracterizado, e no campo penal não tem sido nem um pouco diferente, por fazer exatamente o contrário. Estamos, em termos penológicos, ouvindo e reproduzindo o mesmo há mais de 200 anos, inobstante o rotundo fracasso dos sistemas penais baseados na pena privativa de liberdade. Não satisfeitos, nós, os modernos, radicalizamos esse sistema com a Nova Penologia. Estamos num beco do qual não conseguimos sair, em que a interpelação produtora da técnica, objetivamente, é sempre determinante do nosso agir, pensar e conduzir. A interpelação da técnica nos substitui em nossas decisões e ações. Substitui-nos em nossa responsabilidade, uma vez que ela nos oferece tudo já previamente delimitado. Substitui-nos naquilo que mais nos caracteriza em nossa humanidade, segundo Heidegger, que é o sermos "pastores do ser" (1967), cuidadores do ser (1974).

A nova ética é essa da decisão e do encargo por si mesmo, ou seja, pela responsabilidade do cuidar de nosso destino histórico cuidando do Outro, de sua precariedade, numa espécie de versão negativa do narcisismo, como diria Levinas. Conforme as concepçóes de humano ou não humano que desvelamos, damos um ou outro sentido ao nosso destino. E nisso, parece que temos, dentro de um pensar e agir técnico, relegado a um plano absolutamente inferior a precariedade das outras vidas, ao não representá-las como humanas. Nesse aspecto, ampla razão assiste a Butler, quando argumenta: 
Quando considerarmos as formas comuns de que nos valemos para pensar sobre humanização e desumanização, deparamo-nos com a suposiçáo de que aqueles que ganham representação, especialmente autorrepresentaçáo, detêm melhor chance de serem humanizados. Já aqueles que não têm oportunidade de representar a si mesmos correm grande risco de ser tratados como menos que humanos, de serem vistos como menos humanos ou, de fato, nem serem vistos (2011, p. 24).

Representamos o homem-escravo, ou nos autorrepresentamos como livres, e uma parte terrível de nosso destino foi a escravidão e todas suas violências; desvelamos a mulher-coisa, patrimônio do marido, e nossa sorte está marcada por sistemas patriarcais de dominação que até hoje perpetram suas opressóes; trouxemos à luz a normalidade heterossexual, e pusemos em marcha um fluxo de segregaçóes, exclusóes e coaçóes físicas e simbólicas contra os homossexuais; descortinamos a modernidade com o capitalismo e concebemos o capitalista e o proletário, e nossa fortuna está repleta de minorias luxuriosas sem qualquer incômodo moral e multidóes esfomeadas condenadas ao desespero; fizemos aparecer o sedentário-nacional e o nômade-estrangeiro, e o nosso fado está sendo parado em estaçóes férreas de campos de concentração e entrecortado por muros; calculamos o "ser" humano consumidor e o seu reverso, e nossa existência parece estar sendo determinada por extratos de cartóes de crédito ou marginalidade econômica; descobrimos cada vez mais formas específicas de criminosos, e estamos caminhando cada vez mais para dentro das prisóes.

Dar sentido ao nosso destino tem uma relação direta com a representação da alteridade que construímos, com o reconhecimento dos vínculos ético-morais com o Outro, humanizando-o ou desumanizando-o, para sua salvação ou eliminação. Que representaçóes discursivas da alteridade estamos fazendo, quando praticamos o controle, a segregação ou a eliminação do Outro sem maiores preocupaçóes com o fundo ético-político sobre o qual repousam nossas violências? Exclusóes, separaçóes, exceçóes, rejeiçóes, abandonos, recusas, estes parecem ser os caminhos que nos empenhamos em criar calculadamente. Pensamos os seres humanos para fazê-los desaparecer em nossas violências tecnicamente arquitetadas? Criar possibilidades de restringir mais e mais as possibilidades de vida e de liberdade, esse é o sentido 
de nossa "civilizaçáo"? Cada vez mais fica evidente uma certa tendência genocida em nosso modo de ser calculador, especialmente quando calculamos nossas reaçóes violentas aos comportamentos do Outro com os quais não concordamos.

Nesse sentido, açóes administrativas como a Nova Penologia nos colocam, mais uma vez, diante de uma decisão fundamental, que não diz apenas se devemos criar e fazer isto ou aquilo; se devemos assinar tratados desta ou daquela natureza, fazer leis assim ou assado, mas diz respeito à decisão pela nossa humanidade, consistente em podermos ser os autores de nossa destinação histórica. É preciso, contudo, que não nos enganemos acreditando que estamos no comandando quando, na verdade, estamos sendo comandados, especialmente pelas nossas próprias ilusóes sobre quem somos e o que podemos, pois a concepçáo do que é moralmente vinculante não é dada por nós mesmos; ela não procede de nossa autonomia ou de nossa própria reflexividade. Ela chega de lugares desconhecidos, de forma inesperada, involuntária e não planejada (BUTLER, 2011, p. 15). A nova ética diz respeito à redescoberta do lugar do ser humano no universo, e para isso a reflexão meditativa, própria ao modo-de-ser filosófico, é de fundamental importância como espaço de legitimação de nossas açóes dirigidas ao Outro, especialmente quando interpelamos a sua vida, a sua liberdade. Nessa nova ética penal, enfim, o único critério que se impóe por si mesmo, invocando aqui Nietzsche, é a vida. "É preciso estender os dedos, completamente, nessa direção, e fazer o ensaio de captar a assombrosa finesse, de que o valor da vida não pode ser avaliado. Por um vivente não, porque este é parte interessada, e até mesmo objeto de litígio, e não juiz; por um morto não, por uma outra razão (2006, p. 18).

Assim, para fechar o texto, qualquer apreciação ético-política da Nova Penologia deve passar pelo crivo da vida, e equivale a perguntar se ela contribui para favorecê-la ou obstruí-la; submeter as ideias nela contida e sobre as quais se estruturam suas possibilidades de açóes a uma avaliação ético-política é o mesmo que inquirir se são signos de plenitude de vida ou da sua degeneração; estimar as avaliaçôes que dela são feitas significa questionar se é sintoma de vida ascendente ou declinante. 


\section{REFERÊNCIAS}

ANITUA, Gabriel Ignacio. Histórias dos pensamentos criminológicos. Rio de Janeiro: Revan, 2008.

ARENDT, Hannah. A vida do espírito. Trad. Antonio Abranches et al. 2. ed. Rio de Janeiro: Relume Dumará, 1993.

ARISTÓTELES. Metafisica. Edición Trilingüe por Valentin Garcia Yebra. Madrid: Editorial Gredos, 1970.

BAUMAN, Zigmunt. Estado de crisis. Buenos Aires: Paidós, 2016.

BETTIOL, Giuseppe. Direito penal. 6. ed. São Paulo: Revista dos Tribunais, 1966.

BRASIL. Levantamento Nacional de Informaçóes Penitenciárias (Infopen). Brasília, DF: Ministério da Justiça, 2014a.

. Novo diagnóstico de pessoas presas no Brasil. Brasília, DF: Conselho Nacional de Justiça, 2014b.

BUTLER, Judith. Vidas precárias. Contemporânea, São Carlos, SP, v. 1, n. 1, p. 13-34, jan./ jun. 2011.

CHAIKEN, Jan M. Allocation of Emergency Units Response Areas. Nova York, NY: The New York City Rand Institute, 1971. Disponível em: <http://www.rand.org/content/dam/rand/ pubs/reports/2008/P4745.pdf>. Acesso em: 4 mar. 2016.

COPETTI SANTOS, A. L. É constitucional a expansão normativa e controle social no Brasil? Direito e Justiça (URI), Santo Ângelo, RS, v. 16, p. 255-286, 2011.

. Políticas públicas e tratamento da criminalidade numa sociedade democrática.

Revista Direitos Fundamentais \& Democracia (UniBrasil), Curitiba, v. 8, p. 330-346, 2010.

CRITELLI, Dulce. Martin Heidegger e a essência da técnica. Margem, São Paulo, n. 16, dez. 2002.

DELEUZE, Gilles. Conversaçôes. São Paulo: Ed. 34, 2010.

FEELEY, Malcolm M.; SIMON, Jonathan. The New Penology: Notes on the Emerging Strategy of Corrections and Its Implications. Criminology, 449, 1992. Disponível em: <http:// scholarship.law.berkeley.edu/facpubs/718>. Acesso em: 25 fev. 2016.

FERRY, Luc. Aprender a viver. Rio de Janeiro: Objetiva, 2007.

HABERMAS, Jürgen. A crise de legitimação do capitalismo tardio. Rio de Janeiro: Tempo Brasileiro, 2002. 
HAUSNER Jack. Determining the Travel Characteristics of Emergency Service Vehicles. New York, NY: The New York City Rand Institute, 1975. Disponível em: <http://www.rand.org/ content/dam/rand/pubs/reports/2006/R1687.pdf>. Acesso em: 4 mar. 2016.

HEIDEGGER, Martin. Serenidade. Barcelona: Ediciones del Serbal, 1994.

. A época da imagem do mundo. Sendas perdidas. Trad. José Rovira Armengol. 3. ed. Buenos Aires: Losada, 1979.

. Uma Carta. O fim da filosofia ou a questão do pensamento. Trad. Ernildo Stein. São Paulo, Duas Cidades, 1972.

. A questão da técnica. Ensaios e conferências. Trad. Emmanuel Carneiro Leão et al.. Petrópolis: Vozes, 2002.

. El Ser y el Tiempo. Trad. José Gaos, 5. ed. México: Fondo de Cultura Económica, 1974.

. Introdução à metafísica. Trad. Emmanuel Carneiro Leão. Rio de Janeiro: Tempo Brasileiro, 1969.

. Carta sobre o Humanismo. Trad. Emmanuel Carneiro Leão. Rio de Janeiro: Tempo Brasileiro, 1967.

HUDSON, Barbara. Minority Report: prevendo o futuro na vida real e na ficção. In: ZACKSESKI, Cristina; DUARTE, Evandro C. Pisa (Org.). Criminologia e cinema: perspectivas sobre o controle social. Brasília: UniCEUB, 2012. p. 33-48.

IGNALL, Edward; KOLESAR, Peter; WALKER, Warren. Using Simulation To Develop and Validate Analytical Emergency Service Deployment Models. Nova York, NY: The New York City Rand Institute, 1975. Disponível em: <http://www.rand.org/content/dam/rand/pubs/ reports/2008/P5463.pdf>. Acesso em: 4 mar. 2016.

INSTITUTE FOR CRIMINAL POLICE RESEARCH (ICPR). World Prision Breaf. London: University of London, 2016. Disponível em: <http://www.prisonstudies.org/ world-prison-brief-data>. Acesso em: $20 \mathrm{dez} .2016$.

. World Prision Breaf. London: University of London, 2010. Disponível em: <http:// www.prisonstudies.org/world-prison-brief-data>. Acesso em: 20 dez. 2016.

JENNINGS, John B. Analysis of the Night and Weekend Arraignment Parts in the Bronx and Queens Criminal Courts. Nova York, NY: The New York City Rand Institute, 1973. 
LARRETA, Enrique Rodriguez. Transparências obscuras: pensar a complexidade no século XXI. In: MENDES, Candido (Org.); LARRETA, Enrique Rodriguez (Ed.). Complexidade e representação. Rio de Janeiro: Garamond, 2003.

LARSON, Richard C. A Hypercube Queueing Model for Facility Location and Redistricting in Urban Emergency Services. Nova York, NY: The New York City Rand Institute, 1973. Disponível em: <http://www.rand.org/content/dam/rand/pubs/reports/2006/R1238. pdf $>$. Acesso em: 4 mar. 2016.

. Urban Emergency Service Systems: an Iterative Procedure for Aproximating Performance Characteristics. Nova York, NY: The New York City Rand Institute, 1974. Disponível em: <http://www.rand.org/content/dam/rand/pubs/reports/2006/R1493.pdf>. Acesso em: 4 mar. 2016.

. Response of Emergency Units: The Effects of Barriers, Discrete Streets, and One-Way Streets. Nova York, NY: The New York City Rand Institute, 1971. Disponível em: <http://www.rand.org/content/dam/rand/pubs/reports/2006/R675.pdf $>$. Acesso em: 4 mar. 2016.

LEOPOLDO E SILVA, Franklin. Martin Heidegger e a técnica. SCIENTIAE Studia, São Paulo, v. 5, n. 3, p. 369-374, 2007.

LEVINAS, Emmanuel; KERNEY, Richard. Dialogue with Emmanuel Levinas. Albany: Sunny Express, 1986.

LÉVY, Pierre. Ciberdemocracia. Lisboa: Instituto Piaget, 2003.

LIECHENSTEIN, Michael. Reducing Crimes in Apartment Dwelings: A Methodology for Comparing Security Alternatives. New York, EUA: Rand Corporation, 1971.

LIGHT, Jennifer S. From Warfare to Welfare: Defense Intellectuals and Urban Problems in Cold War America. Baltimore, MD: Johns Hopkins University, 2003.

MAGRI, Francisco. Teoria del Diritto Penale. Turin: Chiantore, 1923.

MANZINI, Vicenzo. Trattato di diritto penale italiano. Torino: Utet, 1941.

NIETZSCHE, Friedrich. Crepúsculo dos ídolos. São Paulo: Companhia das Letras, 2006.

NOZICK, Robert. Anarquia, Estado e utopia. Rio de Janeiro: Jorge Zahar Editor, 1991.

PRATT, John. Penal Populism: key ideas in criminology. Nova York: Routledge, 2007. . Scandinavian Exceptionalism in a Era of Penal Excess. British Journal of Criminology, Oxford, UK, v. 48 (2), mar. 2008. 
QUADE, E. S. Systems Analysis Techniques for Planning-Programming-Budgeting. Santa Monica, CA: Rand Corporation, 1966. Disponível em: <http:/www.rand.org/ pubs/papers/P3322.html>. Acesso em: 4 mar. 2016.

QUADE, E. S. et al. Criminal Justice Models: an Overview. Santa Monica, CA: Rand Corporation, 1975.

REEVES, Richard. City Hires Rand Corp. to Study Four Agencies; Police, Fire, Housing and Health to Get Analysis Initial Contract for $\$ 607,000$ Will Cover Six Months. New York Times, Nova York, NY, 9 jan. 1968. Section Columns, p. 31. Disponível em: <http://timesmachine.nytimes.com/timesmachine/1968/01/09/77165250.html>. Acesso em: 25 fev. 2016. RUSCHE, Georg; KIRCHHEIMER, Otto. Punição e estrutura social. Rio de Janeiro: Freitas Bastos, 1999.

ZAFFARONI, Eugenio Raúl et al. Direito Penal Brasileiro I. Rio de Janeiro: Revan, 2003. ŽIŽEK, Slavoj. Violência. São Paulo: Boitempo, 2014. 


\section{ANEXO 1}

Figura 1 - Tendências de Aprisionamento na Europa

e Estados Unidos no período 1950-2010

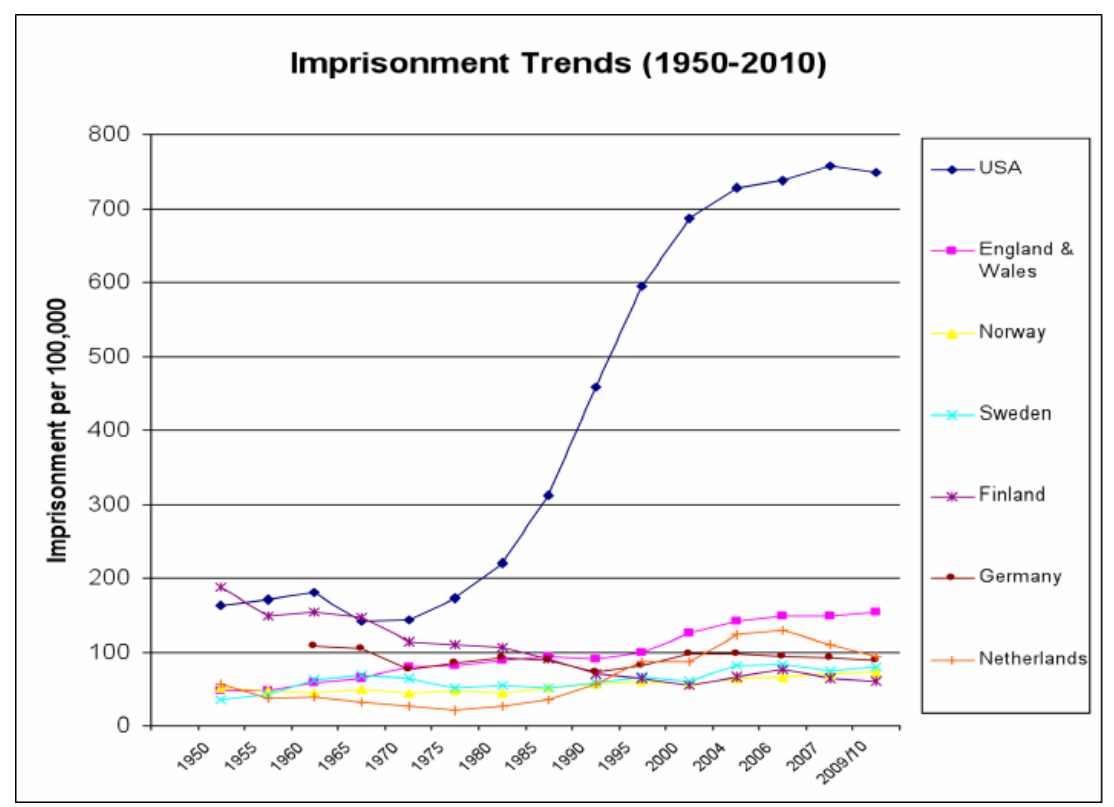

Fonte: INSTITUTE... (2010); PRATT (2008). 


\section{ANEXO 2}

Figura 2 - Quadro Comparativo da Variação da Taxa de Aprisionamento



Fonte: BRASIL (2014a). 